\section{Organizational citizenship behaviors: a glimpse in the light of values and job satisfaction}

\author{
Taís de Andrade \\ Federal University of Santa Maria, Department of \\ Administrative Sciences, Santa Maria, Brazil \\ Vivian Flores Costa \\ Vania de Fátima Barros Estivalete \\ Federal University of Santa Maria, Administrative Sciences \\ Department, Santa Maria, Brazil

\section{Leticia Lengler} \\ Federal University of Santa Maria, Department of \\ Administrative Sciences, Santa Maria, Brazil
}

\begin{abstract}
Purpose - The main goal of this study is to analyze the influence of work related values and work satisfaction on the Organizational Citizenship Behaviors (OCB), according to the perspective of the employees of a company from the education sector.
\end{abstract}

Design/methodology/approach - A survey was carried out with 244 employees of a company located in the state of Rio Grande do Sul, Brazil. The company covers publishers, elementary school and high school levels, and preparative courses for Vestibular (university entrance exam) and Concursos Públicos (exams to be admitted to the civil service), and they are acting in the education sector since 2001.

Findings - The main results reveal that the work related values and work satisfaction positively influence the $\mathrm{OCB}$, and the main values with higher influence on OCB are Conformity, Universalism, Benevolence, and the Satisfaction with the boss, which are the independent variables with higher influence. The only value researched that has no influence on the OCB was Power.

Originality/value - The results will enable a reflection on the reasons that make these individuals work, their satisfaction with the work done and its influence on the organizational citizenship behaviors. Additionally, they may provide subsidies for the education sector, to assess the prospect of their professionals regarding their concerns, interactions and behaviors in the workplace.

Keywords: Organizational citizenship behavior; work values; satisfaction.
Received on

$12 / 17 / 2015$

Approved on

$10 / 13 / 2016$

\section{Responsible editor:}

Prof. Dr. João Mauricio Gama

Boaventura

Evaluation process:

Double Blind Review

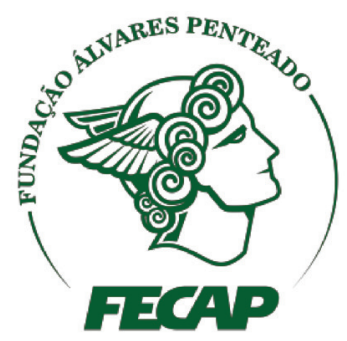

Review of Business Management

DOI: $10.7819 /$ rbgn.v19i64.2899 


\section{Introduction}

In the past 30 years, the interest in organizational citizenship behaviors (OCB) has increased (Podsakoff, Podsakoff, Mackenzie, Maynes, \& Spoelma, 2014), although the literature in Brazil is still incipient in comparison to the international one (Estivalete, Costa \& Andrade, 2014). However, Podsakoff et al. stated that it is possible to identify a certain number of factors that contribute to this tendency of valuing this topic, such as the recognition of $\mathrm{OCB}$ as an important criterium of measurement, which has been developed from other fields. These behaviors might be acknowledged as antecedents of work performance and the organization effectiveness (Organ, 1988; Wang, Law, Hackett, Wang \& Chen, 2005), as well as essential to obtain business competitiveness advantage (Mackenzie, Podsakoff, \& Podsakoff, 2011).

In 1988, Organ argued that it is increasingly necessary to organizations to consider OCB for the spontaneous, innovative and cooperative attitudes in a way to respond to the constantly changing demands aiming to promote efficiency. Yaghoubi, Yazdani and Khornegah (2011) stressed their importance, stating that citizenship behaviors cause individuals to assume a conscious attitude and develop a proactive behavior when facing different organizational situations.

In this OCB field of research, one of the main challenges to the researchers is related to finding their antecedents (Lepine, Erez, \& Johnson, 2002). Among several factors considered predictors of such conducts, some studies have shown the relation between the values and the OCB (Arthaud-Day, Rode, \& Turnley, 2012; Ryan, 2002; Tamayo, 1998). Therefore, it is relevant to highlight the focus on individual values (Elizur \& Sagie, 1999), the work related values, and the $\mathrm{OCB}$, considering that the work related values guide the individuals productive behavior (Porto \& Pilati, 2010), guiding them in the evaluation of what is right or wrong, in the labor context (Judge \& Bretz, 1992).
There is also a research line that focuses on the work attitudes as antecedents of OCB, in which work satisfaction is pointed out as one of the main variables (Bowling, Wang, \& Li, 2012; Podsakoff, Blume, Whiting, \& Podsakoff, 2009; Siqueira, 2003). Bowling et al. (2012) also stress that satisfied employees show more propensity to say good things about their company, to help coworkers, to meet the expectations in relation to their work, because they are willing to repay positive experiences.

Although the relations between work related values and $\mathrm{OCB}$, and the work satisfaction and the OCB, were empirically demonstrated, some doubts still remain, so that researchers suggest that their studies must be expanded (Fassina, Jones \& Uggerslev, 2008; Liang, 2012). Besides, conjecturing about the proposal of this study, it is highlighted that few researches focused on OCB in educational institutions, even though there are some indicators that suggest there might be an impact on efficiency improvement and management in such originations (Bogler $\&$ Somech, 2004; Nasra \& Heilbrunn, 2015).

In this respect, it should be noted that the educational sector has a central role in society. If we consider education as an important instrument of social transformation, it is possible to focus on school as a determinant of new designs that are established in the projection of the future (Monteiro, 2009). It should also be considered that the Brazilian education sector has undergone numerous changes in recent decades, and this context changes are associated to the inclusion of new information and communication technologies, and to the new settings and demands of the working world. These changes brought up with them different pedagogical perspectives about education and new qualification requirements of the education sector professionals.

As Rosa, Catelli and Pauletti (2014) highlight, the changes experienced by this sector range from the use of technology in the classroom, involved in the process of teaching 
and learning, to the potentiation of administrative and professional affairs, demanding from workers new skills and ways of acting in line with the requirements of the current context. In this way, Cruz, Silva and Silva (2015) highlight that the new professional of education must act as a mediator and administrator of knowledge, aiming the development of professionals with competences and abilities to act, create, modify and lead in any sphere of society to which they belong.

So, considering this approach and the relevance of OCB and its antecedents, more specifically regarding the work related values and work satisfaction, to progress in the research of this issue in a joint perspective, specifically in the education sector, makes it a relevant and innovative study. Such analysis will enable a reflection on the reasons that lead these individuals to work, their satisfaction with the work done and its influence on the organizational citizenship behaviors. Such understanding is complex, but can also provide support for the education sector, which assumes social, cultural and political functions, in order to evaluate the perspective of their professionals regarding their concerns, interactions and behaviors in the workplace.

The nature of this research is quantitative, and it was guided through a survey methodology. The object of the study was a company from the educational sector, located in Santa Maria with branches in three cities (Alegrete, Cachoeira do Sul, and Rosário do Sul), in the southern state of Rio Grande do Sul, in Brazil. The research question was: What is the influence of work related values and work satisfaction on organizational citizenship behaviors, according to the perspective of the employees of a company from the educational sector?

Aiming to answer this question, this study has as main goal to analyze the influence of the work related values and work satisfaction on organizational citizenship behaviors, according to the perspective of the employees of a company from the educational sector.
In the following section, the theoretical background related to the study themes will be discussed, and later on, the methodological aspects related to the data collection will be presented, as well as the discussion of results (section four). In the last section, the final considerations about the study will be discussed, pointing out the limitations and suggestions for further researches.

\section{Organizational Citizenship Behaviors}

The pioneer studies about citizenship gather the basis studied by Katz and Kahn (1978) considering the innovative and spontaneous behaviors. These behaviors are associated to cooperation activities with the other organization members, protective actions of the system, creation of an external favorable climate, creative suggestions to maximize organizations and self-training to increase the organizational responsibilities (Katz \& Kahn, 1978). These unofficial specifications have been named Organizational Citizenship Behaviors - OCB (Chhetri, 2014).

The notion of OCB was initially approached by the studies of Organ and his coworkers (Bateman \& Organ, 1983; Organ, 1988). Podsakoff et al. (2014) state that Organ (1988) defines the Organizational Citizenship as an individual behavior, not officially recognized by the formal reward system, which contributes to the efficiency of the organization. These behaviors can also be considered as a combination of interpersonal and volunteer conducts that sustain the social and psychological environment in which they perform the tasks (Organ, 1997).

However, more recent researches (Marinova, Moon, \& Van Dyne, 2010; Podsakoff et al., 2009; Podsakofff et al.; 2014) indicate the potential benefits of a more subtle approach considering its conceptualization in two different aspects. First, employees differ in the way they perceive the behavior of Organizational Citizenship as part of the exercise of their role or extra role in organizations (Van Dyne, Ang, \& Koh, 2008). Second, the OCB is 
sometimes perceived as rewarded by organizations through performance evaluations, promotions or recognition (Marinova et al., 2010).

Considering this approach, the assumptions defended by Blau should be highlighted (1964), where individuals build relationships in the workplace which may be of economic exchange, associated with tangible rewards, and of social exchange, involving the exchange of intangible assets in the socio-emotional and emotional context, such as recognition and esteem. According to the Social Exchange Theory (Blau, 1964), social exchange involves offering favors that create unspecific future obligations, and the nature of the consideration is defined by the individual which should reciprocate. One of the assumptions of this theory emphasizes that the interaction among individuals or communities can be characterized as an attempt to maximize rewards (material and non-material) and reduce costs (material and non-material).

According to Blau's (1964) analysis, the interactions are maintained because people find such interactions more compensatory, independently of the reasons. The social exchange would be based on mutual trust, on unspecified obligations, generating among those involved feelings of personal obligation, gratitude and confidence (Siqueira, 2003). Also in relation to the Social Exchange Theory, the exchange interactions are conceived as a process of central importance in social life and they are considered the basis of the relations among individuals, groups and organizations.

In addition, Eisenberger, Armeli, Rexwinkwl, Lynch and Rhoades (2001), when analyzing the citizenship behavior under an exchange perspective, remind us that the attention is focused on the exchange between the organization and the individual. Thus, in the view of these authors, the Social Exchange Theory has explained the OCB, suggesting that this is expected when the employee is satisfied with the organization and feels motivated to respond reciprocally to the organization.

Much of the research on OCB are based on the Theory of Social Exchange, according to which employees adopt these behaviors to reciprocate positive actions of an organization (Podsakoff et al., 2014; Podsakoff, Mackenzie, Paine, \& Bachrach, 2000; Rapp, Bachrach \& Rapp, 2013). Thus, as stated by Rapp et al. (2013), the Organizational Citizenship Behaviors, driven by feelings of reciprocity, facilitate social interactions among employees, contributing to the realization of work tasks. On the other hand, employees who demonstrate a lower incidence of this behavior are susceptible to having few social exchanges, which may help to reduce the duties.

The complexity surrounding the OCB conceptualization is reflected in the difficulty of its theoretical delimitation (Chhetri, 2014; Podsakoff et al., 2014; Podsakoff et al., 2000; Rapp et al., 2013). Podsakoff et al. (2000) studied the dimensions of OCB with the intention to contribute by building a theoretical framework. Although the literature shows more than 30 different concepts of organizational citizenship, these authors gathered seven main dimensions: altruism, sportsmanship, organizational loyalty, organization compliance, individual initiative, civic virtue and self-development.

Considering OCB dimensions, Williams and Anderson (1991) suggested its classification into two categories: organizational citizenship behavior oriented to organization (OCB-O) and organizational citizenship behavior oriented to other individuals (OCB -I). Following the same number of categories, Van Dyne, Cummings and Parks (1995) classified the OCB dimensions into affiliation orientation and challenges orientation. The OCB oriented to affiliation has interpersonal and cooperative nature, and tend to keep relationship with other people. The OCB oriented to challenges is related to constructive challenges aiming to improvements to the organization and status quo changes (Podsakoff et al., 2014).

In order to compare the different categories suggested by the authors, Table 1 shows the categories of spontaneous and innovative behaviors elaborated by Katz and Kahn (1978), the seven dimensions elaborated by Podsakoff et al. (2000), and the categories proposed by Williams and Anderson (1991) and Van Dyne et al. (1995). 
Table 1

\section{Comparative of OCB dimensions, spontaneous and innovative behavior and OCB Categories}

\begin{tabular}{llll}
\hline $\begin{array}{l}\text { Spontaneous and innovative } \\
\text { behavior categories } \\
\text { Katz and Kahn (1978) }\end{array}$ & $\begin{array}{l}\text { OCB dimensions } \\
\text { Podsakoff et al. (2000) }\end{array}$ & $\begin{array}{l}\text { OCB categories } \\
\text { Williams and Anderson (1991) }\end{array}$ & $\begin{array}{l}\text { OCB categories } \\
\text { Van Dyne et al. (1995) }\end{array}$ \\
\hline Cooperation activities & Altruism & OCB oriented to other individuals & OCB oriented to challenges \\
& Sportsmanship & OCB oriented to the organization & OCB oriented to affiliation \\
$\begin{array}{l}\text { Protective actions of the system } \\
\text { Creation of a friendly mood to } \\
\text { the organization }\end{array}$ & $\begin{array}{l}\text { Organizational loyalty } \\
\text { Creative suggestions }\end{array}$ & OCB oriented to the organization & OCB oriented to affiliation \\
Civic virtue & Individual initiative & OCB oriented to the organization & OCB oriented to challenges \\
\hline
\end{tabular}

Note. Based on "Psicologia social das organizaçôes", by D. Katz and R. L. Kahn, 1978; "Organizational citizenship behaviors: A critical review of the theoretical and empirical literature and suggestions for future research", by P. M. Podsakoff et al., 2000, Journal of Management, 26, 513-563; "Consequences of unit-level organizational citizenship behaviors: A review and recommendations for future research”, by N. P. Podsakoff et al., 2014, Journal of Organizational Behavior, 35, S87-S119; "Job satisfaction and organizational commitment as predictors of organizational citizenship and in-role behaviors", by L. J. Williams and S. E. Anderson, 1991, Journal of Management, 17, 601-617; "Extra-role behaviors: In pursuit of construct and definitional clarity”, by L. Van Dyne, L. L. Cummings and J. M. Parks, 1995, 215-285.

As Table 1 shows, the dimension proposed by Katz and Kahn (1978) is related to the OCB Dimensions suggested by Podsakoff et al. (2000); and to the categories elected by Williams and Anderson (1991) and Van Dyne et al. (1995), considering that the initial studies on innovative and spontaneous behavior served as the base to develop further researches about OCB.

From a national perspective, some contributions came from Siqueira (1995, 2003) and Porto and Tamayo (2003a). Siqueira (1995) is considered the precursor of the theme in Brazil, since she developed the first scale focused on measuring $\mathrm{OCB}$, which considers the five categories of innovative and spontaneous behaviors of Katz and Kahn (1978).

Considering that some dimensions by Siqueira (1995) did not present satisfactory reliability, Porto and Tamayo (2003a) consolidated a different scale. They developed the scale called Scale of Civism in Organizations (Escala de Civismo nas Organizaçóes - ECO) - SCO, composed of 41 items and the same dimensions proposed by Katz and Kahn (1978). All factors of SCO showed in Table 2 presented good reliability, with Cronbach's Alphas values higher than 0.80.

Table 2

Factors of SCO

\begin{tabular}{ll}
\hline Factors & Definitions \\
\hline Creative suggestions to the system & $\begin{array}{l}\text { It represents employees behaviors related to suggestions of new ideas to the administration, in } \\
\text { order to bring benefits to the organization. }\end{array}$ \\
$\begin{array}{l}\text { Protection to the system } \\
\text { Creation of a friendly mood to the } \\
\text { organization }\end{array}$ & $\begin{array}{l}\text { It congregates items about actions aiming to ensure the organization's estate. } \\
\text { the work environment. }\end{array}$ \\
Self-training & $\begin{array}{l}\text { It gathers items on employees' behaviors in search of courses and events to improve their } \\
\text { performance at work. }\end{array}$ \\
Workmate Cooperation & It adds items that reflect behaviors of helping co-workers, aiming benefits to the organization. \\
\hline
\end{tabular}

Note. Based on Porto and Tamayo (2003a). 
In the study proposed by Porto and Tamayo (2003a), the authors used the terminology Organizational Civism, which comprises the spontaneous acts of workers that benefit the organizational system, allowing particular forms of manifestation that do not receive formal retribution from the organization. When we analyze this definition it is possible to perceive the similarity to the OCB concept proposed by Organ (1988). Considering the bibliometric study comprising the past 12 years, Estivalete et al. (2014) state that the SCO has been the most used instrument to research $\mathrm{OCB}$ in the Brazilian context.

In our research, we chose to use the SCO instrument, since it is the most adequate scale to the reality that has been studied and the only scale in Portuguese with satisfactory reliability to measure the Organizational Citizenship Behaviors.

\section{Work values and OCB}

As Cammarosano, Santos and Rojas (2014) present, the work values have been discussed for years, and they are important variables that interfere with managing and organizational behavior.

The work related values are characterized as one of the faces of individual values (Elizur \& Sagie, 1999), and they are described as principles or beliefs about behaviors that guide the evaluation about the results and alternatives of the labor context (Ros, Schwartz \& Surkiss, 1999). To Lee and Yen (2013), these values are an extensive part of the individual system of values, and they are responsible for expressing personal preferences in relation to different qualities of the professional environment.

Considering the interfaces among the individual values, the studies of Schwartz (1992) were the basis for the typology of work values (Ros et al., 1999). Schwartz (1992) established ten types of motivational values, organized in a two-dimensional structure containing two bipolar dimensions: opening to changes (auto determining, stimulation and hedonism), versus conservation (conformity, security and tradition); auto promotion (power, achievement and hedonism) versus auto transcendence (universalism and benevolence). Based on these values, Ros et al. (1999) identified four types of work related values: intrinsic, related to goals obtained according to the work content; extrinsic, referring to goals obtained according to the work results; social pertinence aiming to interpersonal relationship; and prestige, comprehended as the pursuit for the power and recognition through work.

In Brazil, Porto and Tamayo (2003b) also embraced Schwartz's Value Theory that originated the Scale of Work Related Values, SWRV (Escala de Valores Relativos ao Trabalho, EVT). The SWRV indicates four dimensions of work related values associated to work achievement, social relations, prestige and stability. As in some studies the dimensions of SWRV did not present negative correlations among the factors that constitute the opposite poles (Campos, 2008; Porto \& Tamayo, 2007), Porto and Pilati (2010) identified that some factors of the scale did not evaluate the whole theoretical content of the motivational types of Schwartz's Theory.

With the proposal to improve SWRV, Porto and Pilati (2010) developed a research that presented a new version of this scale. The authors named it as Revisited Scale of Work Related Values, R-SWRV (Escala Revisada de Valores Relativos ao Trabalho, EVT-R), and it was consolidated with the six dimensions shown in Table 3.

Table 3

\section{Dimensions of R-SWRV}

\begin{tabular}{ll}
\hline Dimensions & Description \\
\hline Self-determination and stimulation & Associated with thought and independent action , the novelty and challenge \\
Security & Related to financial stability and independence. \\
Conformity & Related to commitment and acceptance of work routines and standardization of the system. \\
Universalism and benevolence & Associated to comprehension, tolerance and protection of others well-being. \\
Realization & Related to personal success by showing competence according to social patterns. \\
Power & Associated to social status and prestige, controlling or dominating other people and resources. \\
\hline
\end{tabular}

Note. Adapted from "Escala revisada de valores relativos ao trabalho-EVT-R" by J. B. Porto and R. Pilati, 2010, Psicologia: Reflexão e Crítica, 23, 73-82. 
It should be noted that in this study we use the R-SWRV as one of the models that make up our research design. This choice was due to the scale showing satisfactory reliability, and due to the improvement in the measurement of work values provided by the instrument, since, according to its authors, the new measurement is even more theoretically appropriate, being closer to the general values model.

The perspectives on work values suggest that they reveal employees' preferences in the labor context as a direct influence on their attitudes and behaviors (Dose, 1997). This way, the values are viewed as a motivational source for the action of individuals (Gursoy, Chi, \& Karadag, 2013), which might influence the definition of norms and common objectives that cause and guide the collective actions (Roe \& Ester, 1999).

In this regard, Ryan (2002), ArthaudDay, Turn and Turnley (2012) and Tamayo (1998) suggest that the values can be considered antecedents of Organizational Citizenship Behaviors. Similarly, Liang (2012) points out that the intrinsic and extrinsic values of work have a significant impact on the OCB. Individuals who prioritize the intrinsic work values (such as selfdetermination and stimulation and realization) tend, for example, to help others with a work overload, protecting the organization's property and obeying the informal rules that are designed to maintain order (Liang, 2012). The priority extrinsic values of work (such as Security and Conformity) show that individuals are willing to demonstrate their organizational citizenship behaviors because these behaviors can lead to greater satisfaction and customer loyalty, which in turn will make them more useful to the organization, and thus they may have more stable careers, increased security and better pay at work (Liang, 2012).

However, as evidenced in a survey conducted regarding the past twenty years by Liang (2012), only three studies specifically evaluated the influence of work values on the OCB. But none of them analyzed the work values from their motivational content, as proposed by the model of Porto and Pilati (2010). Thus, in this study, the influence of work values on the OCB was examined to test the following hypotheses:

\section{H1: Self-determination and stimulation influence the Organizational Citizenship Behaviors.}

H2: Security influences the Organizational Citizenship Behaviors.

H3: Conformity influences the Organizational Citizenship Behaviors.

H4: Universalism and benevolence influence the Organizational Citizenship Behaviors.

H5: Realization influences the Organizational Citizenship Behaviors.

\section{H6: Power influences the Organizational Citizenship Behaviors.}

These hypotheses are supported by the theoretical assumptions defended by Ryan (2002), Arthaud-Day (2012), Tamayo (1998) and Liang (2012), which highlight the influence of the work values on Organizational Citizenship Behaviors.

\section{Work satisfaction and OCB}

The work satisfaction has been studied since the first decades of the XX century, (Siqueira, 2008), since it is a variable that might impact many other important organizational behaviors (Hitt, Miller, \& Colella, 2013). However, the controversies about its concept still remain, and therefore different perspectives, discussed in different contexts, are evident (Andrews, Kacmar, \& Kacmar, 2014).

Initially, the proximity between satisfaction and motivational process was established. This means satisfaction was treated as a motivational element that induced workers to present work behaviors indicators (such as increased productivity 
and development) that were fundamental to the organizations interests (Siqueira, 2008). However, satisfaction and motivation are not the same, despite the concepts of both are associated to each other. (Sangwan, 2013).

Later on, when the human behavior studies were expanded, the work satisfaction was understood as an attitude (Siqueira, 2008). There is another conception, guided by the humanists and social assumptions, which associates satisfaction to the company's social responsibilities, in other words, work satisfaction is a way to monitor how much an organization may promote its workers' health and well-being (Siqueira, 2008).

Among the different conceptions, the classical one was systematized by Locke (1976). The author instituted that work satisfaction is an emotional state, pleasant or positive, that results from the individual's work valorization and experience, in which work related agents and events are the determinants (Imran, Arif, Cheema, \& Azeem, 2014). According to this thought, Martins and Santos (2006) state it is a mental process originated from the evaluation of work experiences that are related to pleasant and unpleasant state.

Table 4

\section{Dimensions of SWS}

\begin{tabular}{ll}
\hline Dimensions & Definitions \\
\hline Satisfaction with workmates & $\begin{array}{l}\text { Contentment with the cooperation, friendship, trust and relationships with their co-workers } \\
\text { Contentment with the received salary as compared to how the individual work with their } \\
\text { professional capacity, to the cost of living and to the efforts made in carrying out the work. } \\
\text { Satisfaction with the salary }\end{array}$ \\
$\begin{array}{l}\text { Contentment with the organization and the professional competence of the superiors, with } \\
\text { their interest in the work of subordinates and the understanding among them. }\end{array}$ \\
$\begin{array}{l}\text { Contentment with the interest aroused by the tasks, with the ability to absorb these works } \\
\text { and the variety of them. }\end{array}$ \\
Satisfaction with nature of work & $\begin{array}{l}\text { Contentment with the number of times he/she was promoted, opportunities for promotion } \\
\text { and the waiting time to get a promotion. }\end{array}$ \\
\hline
\end{tabular}

Note. Based on "Antecedentes de comportamentos de cidadania organizacional: a análise de um modelo pós-cognitivo", by M. M. M. Siqueira, 1995; "Satisfação no trabalho", by M. M. M. Siqueira, 2008.

It is noteworthy that, with the continuation of their work, besides providing a measurement to the construct, Siqueira in 2003 used his archetype of job satisfaction as an
Spector (2012) corroborates stating satisfaction is the degree to which people like their work, represented in a continuum, from the highest to the lowest degree (dissatisfaction). To summarize, Siqueira (2008) gives evidence that the concept of satisfaction is related to affectivity, and it is the affective link between the person and his/her work, in terms of how much the professional has pleasant experiences in the labor context.

Still, because of a lot of researches focusing on what promotes job satisfaction, this construct has to be analyzed in a multifaceted way (Mourão, Monteiro, \& Viana, 2014). Robbins (2008) explains that this concept comprehension is sophisticated, because it identifies some key elements. In this study, we adopt this perspective, and in the development and validation in the Brazilian context, as well as in their psychometric properties, the option is to use the Satisfaction at Work Scale, SWS (Escala de Satisfação no Trabalho, EST), developed by Siqueira (1995). The SWS is a measuring instrument which aims to assess the degree of worker satisfaction across five dimensions of their work, detailed in Table 4.

M. M. Siqueira, 1995; "Satisfação no trabalho", by M. M. M. Siqueira, 2008.

\footnotetext{
2003 used his archetype of job satisfaction as an
}

element of a theoretical framework for explaining organizational citizenship behaviors. This line of research followed by the author focuses on the attitudes at work as antecedents to the OCB, 
where job satisfaction is considered one of the main variables (Siqueira, 2003). With the intent to contribute to such a perspective, our study considers the influence of job satisfaction on the $\mathrm{OCB}$, by testing the following hypotheses:

H7: Satisfaction with workmates influences the Organizational Citizenship Behaviors.

H8: Satisfaction with salary influences the Organizational Citizenship Behaviors.

H9: Satisfaction with boss influences the Organizational Citizenship Behaviors.

H10: Satisfaction with nature of work influences the Organizational Citizenship Behaviors.

H11: Satisfaction with promotions influences the Organizational Citizenship Behaviors.

Hypotheses have got considerable support from studies addressing the effects of job satisfaction on OCB (e.g., Ellinger \& Wu, 2013; Spector, 1997; Williams \& Anderson, 1991). Occasionally, it is noted that one of the first antecedents that got the attention of researchers was the satisfaction (Bateman \& Organ, 1983), this is due to, as it is explained by Organ, Podsakoff and MacKenzie (2006), the belief that attitudes related to work could influence more the adoption of OCB, when compared to other performance measurements linked to the tasks and productivity.

In this sense, Robbins (2008) points out that satisfied employees seem likely to say good things about the company, to help others, to exceed the expectations of their tasks, that is, they seem willing to go beyond their regular duties. More recently, Zeinabadi (2010) indicated that individuals who are satisfied with their work usually reciprocate with positive behavior, including acts with organizational citizenship. However, some investigators recommend the continuation of investigations comprising items in different models (Fassina et al., 2008) and in different contexts, particularly educational, since the studies have been further limited to noneducational settings (Zeinabadi, 2010).

\section{Method}

In order to carry out this study, it is necessary to investigate the following research question: What is the influence of the work related values and work satisfaction on the organizational citizenship behavior, according to the perspective of the employees of a company from the educational sector? Aiming to explore this problem, a descriptive study was performed, from a quantitative perspective, guided by a survey method, used to collect primary data when a great number of people information is required (Hair, Babin, Money, \& Somouel, 2005).

The research was conducted with the employees of a company from the educational sector, located in Santa Maria with branches in Alegrete, Cachoeira do Sul and Rosário do Sul, in Rio Grande do Sul/Brasil. The company acts in the educational sector since 2001, with publishers, elementary school and high school levels, and preparative courses for Vestibular (university entrance exam) and Concursos Publicos (civil service exams).

The choice for the focal company was based on accessibility criteria, importance and organization of representation in its market. Moreover, in the past five years the company has undergone many changes due to the adoption of new information and communication technologies, as well as contextual changes associated to the expansion of the National Examination of Secondary Education (Exame Nacional do Ensino Médio, ENEM), which has driven changes in teaching practices and management. These transformations fomented changes in the education system used by the institution, such as teaching materials, instructional videos and educational planning in general. This context has made the study of the issues addressed in this research further exciting. 
The data collecting instrument was distributed to the 312 employees, and 244 questionnaires returned with proper answers, which represent $78.20 \%$ of the population. The questionnaires were applied to 137 teachers, 59 administrative employees (secretaries, administrative assistants and coordinators), 24 employees responsible for maintenance and cleaning services, and 24 tutors and monitors of classrooms.

The data collecting instrument used was a questionnaire elaborated from three different models. The first model was the Revisited Scale of Work Related Values, R-SWRV (Escala Revisada de Valores Relativos ao Trabalho, EVT-R), developed by Porto and Pilati (2010), that has 38 questions distributed in six dimensions (self-determination and stimulation; security; conformity, universalism and benevolence, realization and power). The second model considered was the short version of Satisfaction at Work Scale, SWS (Escala de Satisfação no Trabalho, EST), elaborated and validated by Siqueira (1995), with 15 questions related to the satisfaction involving: coworkers, salary, subordination, nature of work and promotions. The third model was Scale of Civism in Organizations,
SCO (Escala de Civismo nas Organizaçóes, ECO), develop by Porto and Tamayo (2003a), composed of 41 items and five factors: creative suggestions to the system; protection to the system; creation of a friendly mood to the organization, self-training and workmates cooperation.

It is noteworthy that in the questionnaire development stage, we chose to change the SWS instrument scale from a Likert scale of 7 points to a 5-point scale. As the final questionnaire has a number of alternatives and the scales of other instruments used (R-SVRW and SCO) have a Likert scale of 5 points, this adaptation facilitated the understanding and answering the items of the instruments. As stated by Vieira and Dalmoro (2008), in questionnaires involving a large number of issues, smaller scales should be chosen to reduce the total number of options to be analyzed. Similarly, in the view of these authors, the use of scales with different formats should be avoided to prevent making the respondents confused.

The layout of the research is presented in Figure 1, in order to facilitate the understanding of the theoretical models and dimensions that were used to compose this particular study.

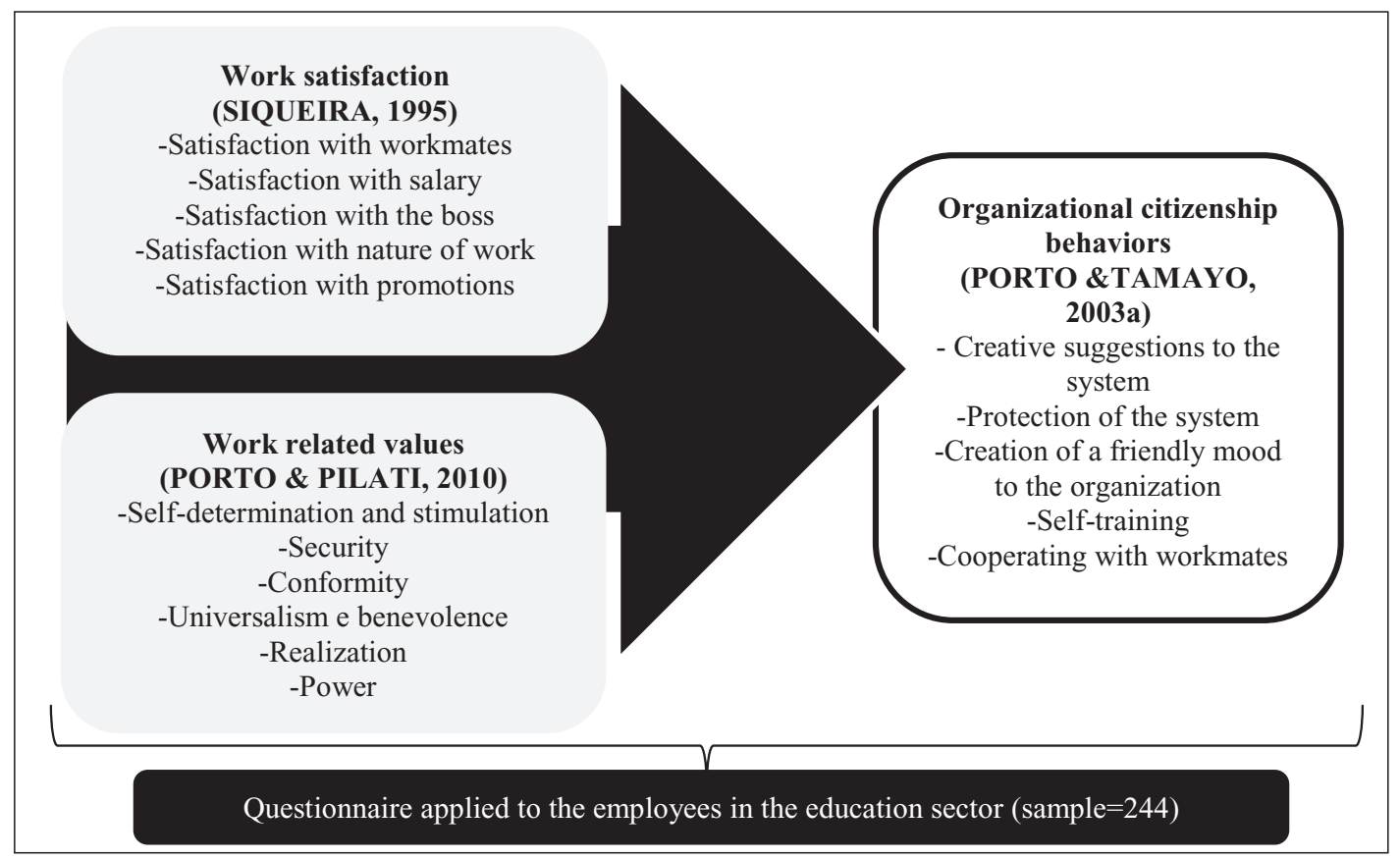

Figure 1. Layout of the research 
The data analysis was performed using the support software SPSS (Statistical Package for the Social Sciences) to use the statistic tests. Initially, the descriptive analysis was done using medium and standard deviation. Later, the data from R-SWRV, SWS and SCO models were run with exploratory factorial analysis. The indicator of Cronbach's Alpha was used aiming to verify the reliability of the model's constructs.

The Pearson Correlation Coefficient was used to establish the relation among the factors of work values (work satisfaction and organizational citizenship behavior), which indicates the association strength between two variables (Hair et al., 2005). The last index used was the Regression Coefficients in which the dependent variables are the OCB dimensions and the independent variables are the work related values and work satisfaction.

In the present study, a survey was conducted, drawing on quantitative data to obtain information about the investigated phenomenon. However, while recognizing the benefits of that research strategy for carrying out this work, the limits of the study have to be considered. The first rests on its scope, since the sample used was characterized by being non-probabilistic for convenience, and the results and conclusions obtained are restricted to the reality studied. So, to make generalizations about the education sector it is important to enlarge the sample of investigated individuals and organizations.

Another item that can be pointed out as a limitation refers to performing a purely quantitative research, since it is recommended to use in subsequent studies multi-method methodologies, aiming to deepen the results.

\section{Results}

In this section, the description of the investigated sample is presented. After the descriptive statistics, the main results of the research are divided into sub topics, according to the objectives that were delimitated in the introduction of this study.

From the 244 employees researched, $57.7 \%$ are female and $42.3 \%$ are male. The average age is 33 years old, and regarding education $48.7 \%$ have post-graduation level. The interviewed people work at the Teaching section (55.7\%), Administrative (22.3\%), Cleaning and maintenance (9.4\%), and Teaching Support (9\%).

\section{I The employees' view about work related values, work satisfaction and $O C B$}

In order to learn about the employees' view about work related values, work satisfaction and organizational citizenship behaviors, the statistic technique of exploratory factor analysis was used for each construct separately. It was chosen for adopting the analysis of the main components as a method to extract dimensions, and varimax as a method of rotation.

The three scales had items excluded for presenting commonality values less than 0.5 (Hair, Black, Babin, Anderson \& Tatham, 2009). As we can see, according to data presented in Table 5, in the Revisited Scale of Work Related Values (R-SWRV) and Satisfaction at Work Scale (SWS), three items were excluded from each, and from Scale of Civism in Organizations (SCO), one item was excluded. It is appropriate to note that the totality of the excluded items from SWS referred to the factor Satisfaction with the nature of work, which presented the value of 0.77 on the reliability test of Porto and Pilati's (2010) original scale.

$\mathrm{KMO}$ has been shown as satisfactory for all scales $(0.837 ; 0.862 ; 0.853)$, as well as the Bartlett sphericity test.

Table 5

Main components of the scales analysis

\begin{tabular}{llllll}
\hline Scale & Items excluded by commonality & KMO & Bartlett $\boldsymbol{s i g}$ & Factors & Cumulative Explained Variance \\
\hline R-SWRV & 7.35 .36 & 0.837 & 0.000 & 9 & $64.47 \%$ \\
SWS & 5.8 .13 & 0.862 & 0.000 & 3 & $72.51 \%$ \\
SCO & 15 & 0.853 & 0.000 & 9 & $67.38 \%$ \\
\hline
\end{tabular}


Another criterium used in the analysis refers to the variance percentage explained by the factors, whose satisfactory level should concentrate at around 60\% (Hair, Black, Babin, Anderson, \& Tatham, 2009), which was attained in the three scales. Besides, it is highlighted that the measuring analysis for sample and anti-image correlation matrix adequacy were also satisfactory for factor analysis.

Later, in order to analyze the reliability of the facts, Cronbach's Alpha reliability test was used, which can present a coefficient varying from 0 to 1 , and numbers higher than 0.7 indicate satisfactory reliability of internal consistency (Hair et al., 2009). To facilitate de appreciation of the findings, it was decided to present the factor analysis of each scale separately.

Concerning R-SWRV, from those nine factors found during the analysis of the main components of the scale, three were excluded for presenting low reliability. This way, the six factors resulting from the factor analysis are presented in Table 6.

As we can note from data presented in Table 6 , some variables were allocated in factors different from the original ones, however, coherence between such variables and the factor direction are noted. The first factor shows the prevalence of the direction Universalism and Benevolence (UB) from the original model, and only one variable (22 - Having constant challenges), arising from the factor Self-determination and Stimulation, has joined this factor. This variable, in such a way, can complement the factor direction as long as challenges can be related to the motivation to promote other people's well-being, transcending individual concerns (Schwartz, 1992).

The second factor gathers five variables from the model proposed by Porto and Pilati (2010). It is noted that this factor's focus is on personal success through competence demonstration in accordance with social patterns (Porto \& Pilati, 2010). The same way, all the variables from the original model are included in factor 3, revealing a certain stability of the model in relation to this dimension. The factor Security relates to financial stability and independence, according to Porto and Pilati (2010).
Factor 4, named Self-determination and stimulation, features four variables, but it is mandatory to note that three variables from the original model concerning that dimension were gathered in different factors. The fifth factor, for example, brings two from the variables originated from Self-determination and stimulation. However, certain coherence is perceived in this group, since factor 5, named Power, is associated to social status and prestige, which can promote knowledge of new places and people, according to variables 33 and 34 .

Finally, two items from the factor Conformity and one item from Self-determination and stimulation were added to factor 6 . The variable originated from Self-determination and stimulation may complement the factor since the development of new abilities can be considered essential for the achievement of commitment and acceptance of work norms and routines.

Concerning the second model, the reduced version of SWS, it is seen that none of the three factors initially found were excluded in this stage. Therefore, the results from the factor analysis are presented in Table 7.

It is observed that SWS, in its reduced version, has resulted in three factors from the six of the original model. In the first obtained factor, we can observe a higher incidence of variables that belong to Satisfaction with salary and Satisfaction with promotions, thus being named Satisfaction with salary and promotions. Originally, the factor Satisfaction with salary obtained Cronbach's Alpha 0.90 and the factor Satisfaction with promotions, 0.81 in that reliability test, while Satisfaction with salary and promotions in this study resulted in a Cronbach's Alpha of 0.91, being the association of those two relevant factors.

Still, it is highlighted that factor 2, Satisfaction with the boss, has remained the same as the original factor, which presents a Cronbach's Alpha of 0.84 in the original scale and 0.89 in the present research. The third factor's composition, Satisfaction with workmates, has also remained the same, but obtained 0.81 in the reliability test in the original scale and 0.75 in this study. 
Table 6

Factor analysis and average answers about R-SWRV

\begin{tabular}{|c|c|c|c|c|c|}
\hline Description & $\begin{array}{c}\text { Original } \\
\text { Factor }\end{array}$ & Charge & $\begin{array}{l}\text { Avg. } \\
\text { var. }\end{array}$ & $\begin{array}{l}\text { Avg. } \\
\text { factor }\end{array}$ & $\begin{array}{l}\text { Standard } \\
\text { deviation }\end{array}$ \\
\hline \multicolumn{6}{|l|}{ FACTOR 1 - Universalism and benevolence $(\alpha=0.827)$} \\
\hline 2. Collaborating to society's development & UB & 0.834 & 4.39 & \multirow{6}{*}{4.17} & \multirow{6}{*}{0.566} \\
\hline 3. Fighting social inequalities & UB & 0.781 & 4.28 & & \\
\hline 18. Being useful to society & UB & 0.689 & 4.15 & & \\
\hline 1. Helping others & UB & 0.656 & 4.37 & & \\
\hline 21. Having social commitment & UB & 0.585 & 4.02 & & \\
\hline 22. Having constant challenges & $\mathrm{AE}$ & 0.458 & 3.83 & & \\
\hline \multicolumn{6}{|l|}{ FACTOR 2 - Realization $(\alpha=\mathbf{0 . 8 3 8})$} \\
\hline 16. Being recognized by satisfactory result from my work & $\mathrm{R}$ & 0.785 & 4.36 & \multirow{5}{*}{4.32} & \multirow{5}{*}{0.600} \\
\hline 13. Being admired for my work & $\mathrm{R}$ & 0.776 & 4.18 & & \\
\hline 17. Being respected for my competences at work & $\mathrm{R}$ & 0.741 & 4.31 & & \\
\hline 4. Demonstrating my competences & $\mathrm{R}$ & 0.627 & 4.31 & & \\
\hline 14. Being successful in my profession & $\mathrm{R}$ & 0.561 & 4.43 & & \\
\hline \multicolumn{6}{|l|}{ FACTOR 3 - Security $(\alpha=0.829)$} \\
\hline 6. Obtaining financial stability & S & 0.795 & 4.27 & \multirow{5}{*}{4.26} & \multirow{5}{*}{0.571} \\
\hline 11. Being able of financially support myself & $S$ & 0.791 & 4.57 & & \\
\hline 8. Making Money & $S$ & 0.736 & 3.80 & & \\
\hline 15.Being financially independent & S & 0.704 & 4.41 & & \\
\hline 25. Having better life conditions & $S$ & 0.656 & 4.27 & & \\
\hline \multicolumn{6}{|l|}{ FACTOR 4 - Self-determination and stimulation $(\alpha=\mathbf{0 . 7 8 0})$} \\
\hline 24. Having freedom to decide how to do my job & SD & 0.824 & 3.85 & \multirow{4}{*}{4.00} & \multirow{4}{*}{0.633} \\
\hline 20. Having autonomy in the fulfillment of my tasks & SD & 0.733 & 4.07 & & \\
\hline 30. Having a creative work & SD & 0.604 & 4.03 & & \\
\hline 31. Having an innovative work & SD & 0.461 & 4.04 & & \\
\hline \multicolumn{6}{|l|}{ FACTOR 5 - Power $(\alpha=0.729)$} \\
\hline 23. Having fame & $\mathrm{P}$ & 0.746 & 1.95 & \multirow{5}{*}{3.14} & \multirow{5}{*}{0.682} \\
\hline 26. Having prestige & $\mathrm{P}$ & 0.610 & 3.10 & & \\
\hline 33. Having a job that allows me to know new places & SD & 0.606 & 3.29 & & \\
\hline 34. Having a job that allows me to meet new people & SD & 0.500 & 3.53 & & \\
\hline 37. Having a socially recognized profession & $\mathrm{P}$ & 0.432 & 3.80 & & \\
\hline \multicolumn{6}{|l|}{ FACTOR 6 - Conformity $(\alpha=0.715)$} \\
\hline 5. Developing new abilities & SD & 0.614 & 4.46 & \multirow{3}{*}{4.44} & \multirow{3}{*}{0.573} \\
\hline 12. Respecting hierarchy & $\mathrm{C}$ & 0.554 & 4.31 & & \\
\hline 10. Complying with work norms & $\mathrm{C}$ & 0.512 & 4.55 & & \\
\hline
\end{tabular}

Note. $\mathrm{UB}=$ Universalism and Benevolence; $\mathrm{R}=$ Realization; $\mathrm{S}=$ Security; $\mathrm{SD}=$ Self-determination and stimulation; $\mathrm{P}=$ Power; $\mathrm{C}=$ Conformity. 
Table 7

Factor analysis and average answers about reduced version of SWS

\begin{tabular}{|c|c|c|c|c|c|}
\hline Description & $\begin{array}{l}\text { Original } \\
\text { Factor }\end{array}$ & Charge & $\begin{array}{l}\text { Avg. } \\
\text { var. }\end{array}$ & $\begin{array}{l}\text { Avg. } \\
\text { factor }\end{array}$ & $\begin{array}{l}\text { Standard } \\
\text { deviation }\end{array}$ \\
\hline \multicolumn{6}{|l|}{ FACTOR 1 - Satisfaction with salary and promotions $(\alpha=0.903)$} \\
\hline 6. With my salary compared to my professional capacity & SS & 0,903 & 3,52 & \multirow{6}{*}{3,61} & \multirow{6}{*}{0,750} \\
\hline 3. With my salary compared to how much I work & SS & 0,867 & 3,71 & & \\
\hline 11. With my salary compared to my efforts at work & SS & 0,865 & 3,59 & & \\
\hline 9. With opportunities to be promoted by the business & SP & 0,715 & 3,68 & & \\
\hline 7. With the way this business promotes its staff & SP & 0,701 & 3,51 & & \\
\hline 2. With the number of times I have already been promoted in this business & SP & 0,646 & 3,66 & & \\
\hline \multicolumn{6}{|l|}{ FACTOR 2 - Satisfaction with the boss $(\alpha=0.894)$} \\
\hline 10. With the understanding between me and my boss & SC & 0,887 & 4,42 & \multirow{3}{*}{4,39} & \multirow{3}{*}{0,598} \\
\hline 15. With my boss' professional capacity & SC & 0,838 & 4,36 & & \\
\hline 12. With the way my boss treats me & SC & 0,834 & 4,38 & & \\
\hline \multicolumn{6}{|l|}{ FACTOR 3 - Satisfaction with workmates $(\alpha=0.749)$} \\
\hline 4. With the kind of friendship my workmates show toward me & SCT & 0,801 & 4,31 & \multirow{3}{*}{4,17} & \multirow{3}{*}{0,569} \\
\hline 14. With the confidence I can have in my workmates & SCT & 0,784 & 4,05 & & \\
\hline 1. With my workmates collaborative spirit & SCT & 0,766 & 4,15 & & \\
\hline
\end{tabular}

Note. SSP = Satisfaction with salary and promotions; SS = Satisfaction with salary; SP = Satisfaction with promotions; $\mathrm{SB}=$ Satisfaction with the boss; SW = Satisfaction with workmates.

Concerning SCO, three factors were excluded from the nine ones found in the beginning of the test, considering unsatisfactory values in the reliability test. The six resulting factors are shown in Table 8.

Table 4

Factor analysis and average answers about SCO

\begin{tabular}{|c|c|c|c|c|c|}
\hline Description & $\begin{array}{l}\text { Original } \\
\text { Factor }\end{array}$ & Charge & $\begin{array}{l}\text { Avg. } \\
\text { var. }\end{array}$ & $\begin{array}{l}\text { Avg. } \\
\text { factor }\end{array}$ & $\begin{array}{l}\text { Standard } \\
\text { deviation }\end{array}$ \\
\hline \multicolumn{6}{|l|}{ FACTOR 1 - Creative suggestions to the system $(\alpha=0.919)$} \\
\hline 25. I give suggestions to improve the business' structures & CSS & 0.831 & 3.80 & & \\
\hline 29. I give suggestions to improve the sector's working & CSS & 0.785 & 4.08 & & \\
\hline $\begin{array}{l}\text { 35. I give suggestions about the physical environment's disposition } \\
\text { of my area }\end{array}$ & CSS & 0.780 & 3.71 & & \\
\hline 11. I give suggestions about new products and services & CSS & 0.756 & 3.60 & & \\
\hline 32. I give new ideas to increase productivity & CSS & 0.751 & 3.98 & & \\
\hline $\begin{array}{l}\text { 2. I contribute with new ideas for the best use of the physical } \\
\text { environment }\end{array}$ & CSS & 0.746 & 3.80 & 3.87 & 0.790 \\
\hline 34. I contribute with suggestions to improve the business' management & CSS & 0.704 & 3.39 & & \\
\hline 22. I think about new uses for inactive equipment & CSS & 0.623 & 3.83 & & \\
\hline 1. I give suggestions to solve problems in the department where I work & CSS & 0.559 & 4.03 & & \\
\hline $\begin{array}{l}\text { 4. I contribute with new routines which can improve my department's } \\
\text { performance }\end{array}$ & CSS & 0.513 & 4.24 & & \\
\hline 14. I pass along new ideas about my work in this business & CSS & 0.492 & 4.18 & & \\
\hline
\end{tabular}




\begin{tabular}{|c|c|c|c|c|c|}
\hline Description & $\begin{array}{l}\text { Original } \\
\text { Factor }\end{array}$ & Charge & $\begin{array}{l}\text { Avg. } \\
\text { var. }\end{array}$ & $\begin{array}{l}\text { Avg. } \\
\text { factor }\end{array}$ & $\begin{array}{l}\text { Standard } \\
\text { deviation }\end{array}$ \\
\hline \multicolumn{6}{|l|}{ FACTOR $2-$ Creation of a friendly mood to the organization $(\alpha=0.841)$} \\
\hline 27. I provide good information about this business & CFM & 0.835 & 4.86 & \multirow{8}{*}{4.65} & \multirow{8}{*}{0.465} \\
\hline 39. I advocate for products or services from this business & CFM & 0.713 & 4.81 & & \\
\hline $\begin{array}{l}\text { 23. I am used to passing along the best impression to people who do not } \\
\text { know this business }\end{array}$ & CFM & 0.704 & 4.88 & & \\
\hline 3. I try to advocate for the business I work for & CFM & 0.667 & 4.71 & & \\
\hline 18. I describe the qualities of this business & CFM & 0.643 & 4.71 & & \\
\hline 28. I inform about this business' role in society & CFM & 0.595 & 4.60 & & \\
\hline 12. I am used to praising this organization & CFM & 0.550 & 4.33 & & \\
\hline 31. I talk about the advantages of working in this business & CFM & 0.478 & 4.41 & & \\
\hline \multicolumn{6}{|l|}{ FACTOR 3 - Cooperating with workmates $(\alpha=0.808)$} \\
\hline 20. I offer myself to help a workmate who is having difficulties at work & CWW & 0.749 & 4.71 & \multirow{6}{*}{4.56} & \multirow{6}{*}{0.505} \\
\hline 40. I help workmates at solving problems & CWW & 0.736 & 4.57 & & \\
\hline 37. I offer workmates with personal problems emotional support & CWW & 0.672 & 4.15 & & \\
\hline 30. I complement my work mates' works when requested & CWW & 0.638 & 4.52 & & \\
\hline 38. I collaborate when my workmates ask me for help at work & CWW & 0.612 & 4.80 & & \\
\hline 21. I transmit my knowledge to my workmates & CWW & 0.594 & 4.63 & & \\
\hline \multicolumn{6}{|l|}{ FACTOR 4 - Self-training $(\alpha=0.891)$} \\
\hline 5. I attend professional improvement courses & ST & 0.871 & 3.52 & \multirow{4}{*}{3.81} & \multirow{4}{*}{0.975} \\
\hline 33. I search for complementary courses that broaden my field & ST & 0.865 & 3.86 & & \\
\hline 10. I try to attend professional updating courses & ST & 0.851 & 3.74 & & \\
\hline 36. I try to participate in events in my field & ST & 0.695 & 4.18 & & \\
\hline \multicolumn{6}{|l|}{ FACTOR 5 - Protection of the system $(\alpha=0.721)$} \\
\hline 19. I take a good care of working equipment & PS & 0.820 & 4.91 & \multirow{5}{*}{4.82} & \multirow{5}{*}{0.285} \\
\hline 24. I use this business' equipment with care & PS & 0.711 & 4.93 & & \\
\hline 6. I use this business' equipment adequately & PS & 0.696 & 4.81 & & \\
\hline 7. I avoid wasting this business' material & PS & 0.652 & 4.87 & & \\
\hline 8. I accomplish tasks in more efficient ways & CCS & 0.382 & 4.58 & & \\
\hline \multicolumn{6}{|l|}{ FACTOR 6 - Working environment preservation $(\alpha=0.729)$} \\
\hline 17. I try to know my working equipment & PS & 0.807 & 4.88 & \multirow{2}{*}{4.87} & \multirow{2}{*}{0.359} \\
\hline 16. I take a good care of working environment cleanness & PS & 0.798 & 4.86 & & \\
\hline
\end{tabular}

Note . CSS = Creative Suggestions to the System; CFM = Creation of a friendly mood to the organization in external environment; CWW = Cooperating with workmates; ST = Self-training; PS = Protection of the system; WEP = Working environment preservation.

SCO presents five factors in its original configuration, this study having created one more factor called Working environment preservation due to the fact that two variables from the factor Protection of the system have formed a separate factor. Those variables were " 17 . I try to know my working equipment" and " 16 . I take a good care of working environment cleanness".

Besides, it is highlighted that item " 8 . I accomplish tasks in more efficient ways", originally from the factor "Creative Suggestions to the System", was allocated in Protection of the system. Such event is understandable, since the efficiency in tasks can be related to the care with the organization's properties, especially with other two items that compose the factor, namely "7. I avoid wasting this business' material" and " 6 . I use this business' equipment adequately”.

Thus, as seen in the results shown in Tables 6,7 , and 8 , the three scales presented satisfactory 
measurements, testifying the effectiveness of the used tools. This way, after considering the factor analysis, it was proceeded with the verification of averages and standard deviations for the established factors in each of the three explored constructs, also presented in Tables 6, 7, and 8.

Firstly, concerning work related values, results in Table 6 show that the primary values, in the perspective of the subjects, are Conformity (4.44), Realization (4.32), and Security (4.26), whereas Self-determination and stimulation (4.00), Universalism and benevolence (4.17), and Power (3.14) occupied lower positions in the priority hierarchy. These results may be associated with the profile of respondents, mostly female, average age of 33 years old, high education (postgraduate) and, many of them having children. As pointed out by Ros, Schwartz and Surkis (1999), employees who prioritize values related to stability seek security at work, in order to have an income necessary to maintain order in their lives.

In relation to work satisfaction, the employees' evaluation has shown bigger contentment with Satisfaction with the boss (4.39) and Satisfaction with workmates (4.17). On the opposite side, the lowest score obtained was for Satisfaction with salary and promotions (3.61), which indicated a lesser satisfaction of the employees with payment received when compared to the efforts required by the work and their professional capacity, as well as the business's promotion system.

Concluding, concerning $\mathrm{OCB}$, it was observed that Working environment preservation (4.87), Protection of the system (4.82), and Creation of a friendly mood to the organization (4.65) behaviors were indicated by the employees as the most present in the investigated organizational context. On the other hand, evidences indicated that Creative suggestions to the system (3.87) and Self-training (3.81), factors that consider acts of suggesting new ideas to the administration and related to the search of training that could maximize individual performance, respectively, are the ones less practiced in the working environment. These results can also be associated with the profile of the respondents and the characteristics inherent to the educational sector, which can stimulate through its practices the preservation of the work environment, protection system and creating a climate favorable to the organization.

\subsection{Influence of work related values and of satisfaction at work over OCB}

Aiming to analyze the influence of work related values and of satisfaction at work over organizational citizenship behaviors, multiple regression analyses were performed to identify which OCB dimensions (dependent variables) are explained by the factor of working values and by satisfaction at work (independent variables).

Concerning the method, for the elaboration of regression models, stepwise regression was used to allow examining the contribution of each independent variable to the regression model, and each variable is considered for inclusion before developing the equation, aiming at the most adequate model (Hair et al., 2009).

Initially, the $F$ test was carried, assessing the global significance of the regression, and it was observed that all the values of the test were significant at $1 \%$ indicating that at least one of the variables influences dependent variables, adding relevance to proposed models (Pestana \& Gageiro, 2008). Thus, the models presented for dependent variables associated to organizational citizenship behaviors are presented in Table 9.

The results from multiple regressions revealed five factors of work related values and three factors of satisfaction at work as predictors of organizational citizenship behaviors: Universalism and benevolence, Realization, Security, Self-determination and stimulation, Conformity, Satisfaction with salary and promotions, Satisfaction with the boss, and Satisfaction with workmates. Only the value Power did not influence the dependent variables associated to OCB. 
Table 9

Values of constant, Beta coefficient, and adjusted coefficient of determination $\left(R^{2}\right)$ for the regression models

\begin{tabular}{|c|c|c|c|c|c|c|c|c|c|c|}
\hline \multirow{2}{*}{ Dependent Variable } & Const. & $\begin{array}{c}\text { Univ. and } \\
\text { benev. }\end{array}$ & Realiz. & Secur. & $\begin{array}{c}\text { Self. and } \\
\text { estim. }\end{array}$ & Confor. & $\begin{array}{c}\text { Satis } \\
\text { salary }\end{array}$ & $\begin{array}{l}\text { Satis. } \\
\text { Boss } \\
\end{array}$ & $\begin{array}{c}\text { Satis. } \\
\text { Workmates } \\
\end{array}$ & $\mathbf{R}^{2}$ \\
\hline & Value & Coef. & Coef. & Coef. & Coef. & Coef. & Coef. & Coef. & Coef. & Adj \\
\hline Creative suggestions & 1.001 & 0.451 & & & & & 0.147 & 0.183 & 0.039 & 0.153 \\
\hline Friendly mood & 2.316 & & 0.130 & & & 0.201 & 0.067 & 0.202 & 0.060 & 0.265 \\
\hline Workmate cooperation & 2.557 & 0.171 & 0.036 & 0.074 & 0.067 & & & 0.246 & & 0.130 \\
\hline Self-training & 1.490 & 0.412 & & 0.298 & 0.332 & 0.424 & 0.002 & & & 0.272 \\
\hline Protection of the system & 4.182 & & & & & 0.038 & & & & 0.061 \\
\hline Environment preservation & 4.013 & & & & & 0.105 & & 0.089 & & 0.062 \\
\hline General Citizenship & 2.259 & 0.191 & & & & 0.204 & & 0.107 & & 0.340 \\
\hline
\end{tabular}

Note. ${ }^{*}$ sig $<0.05$.

In relation to the proposed model, it was verified that the work related values Conformity and Universalism and benevolence were the dependent variables that most influenced the factors of organizational citizenship behavior. Conformity influenced the models represented by the dependent variables Creation of a friendly mood to the organization in external environment (Friendly mood), Self-training, Protection of the system, Environment preservation and General citizenship. Universalism and benevolence influenced the models associated to Creative suggestions, Cooperation with workmates, Selftraining and General citizenship.

A better understanding of the observed results can be obtained by examining the specific objectives of the most influential OCB predictors. The motivational content of the value related to work Conformity is associated to the acceptance of norms and hierarchy (Porto \& Pilati, 2010), action restriction, inclinations and impulses that tend to disturb others and that violate social norms, serving to collective interests (Schwartz, 1992). Universalism and benevolence refers to the preservation and strength of close people's well-being, as well as tolerance, comprehension and protection of collective well-being (Schwartz, 1992).

Therefore, it is understandable that values Conformity and Universalism and benevolence are the independent variables that most positively influenced $\mathrm{OCB}$, specifically associated to the creation of a friendly mood to the organization, selftraining, protection of the system, environment preservation, creative suggestions and cooperation with workmates. Such OCB dimensions are associated to organizational citizenship behaviors oriented to organization in general, specified by Williams and Anderson (1991) as acts capable of benefiting the organization in general, as for example protection and support to the business (Podsakoff et al., 2014). The same way, Shao, Resick and Hargis (2011) found that the values associated to collectivism were positively associated to citizenship behaviors.

Concerning factors of work satisfaction, it was verified that the factor Satisfaction with the boss (Satis. boss) was the independent variable that most influenced the dependent variables related to the OCB. Satisfaction with the boss influenced the models represented by the dependent variables Creative suggestions, Creation of a friendly mood to the organization in external environment (Friendly mood), Cooperation with workmates, Environment preservation and General citizenship.

For Swaminathan and Jawahar (2013), the work satisfaction influences OCB, being also evident, through a study carried out in the educational sector, the positive relation between satisfaction and the factors that constitute the OCB. The same way, Bowling et al. (2012) found 
that the construct Work Satisfaction is considered a potential antecedent of OCB. Specifically, in relation to satisfaction with the boss, Siqueira (2008) states that this one refers to the contentment with the organization and professional capacity of the boss, to his/her interest in the employees' work, and the understanding between them (Siqueira, 1995, 2008). Thus, as the results of the present study show, satisfaction with the boss positively influences OCB factors, contributing to behaviors related to the suggestions of new ideas, advertising business' merits and advantages and helping workmates (Porto \& Tamayo, 2003a).

In relation to the dependent variable percentage explained by independent variables, identified through the adjusted determination coefficient ( $\mathrm{R}^{2}$ Adj.), it is highlighted that the model represented by the dependent variable General citizenship presented the biggest value, indicating that $34 \%$ of the factor variance can be explained by the values Universalism and benevolence, Conformity and by the factor Satisfaction with the boss. Such findings show that the priority of working values associated to selftranscendence, which gathers the transcendence of personal interests in favor of the others' well-being and the fulfillment of collective rules and norms, positively influences organizational citizenship behaviors. This way, it is understood that the bigger the priorities to values Universalism and benevolence and Conformity are, more ratified OCB will be. Besides, evidences also suggest that positive perception in relation to the boss' performance can favor and encourage OCB.

The second model with the bigger adjusted determination coefficient was represented by the dependent variable Self-training, which obtained $27.20 \%$ of variance explained by the factors Universalism and benevolence, Security, Self-determination and stimulation, Conformity, and Satisfaction with salary. These findings point to the importance of these work related values as predictors of OCB related to Self-training, which comprehends the employees' behaviors in search of a qualification that enables the improvement of their performance at work (Porto \& Tamayo, 2003a).

It is also highlighted the positive influence of values Security and Self-determination and stimulation over the dimension Self-training. The aforementioned work related values belong to opposing axis, the former being associated to conservation and the latter to the opening to change (Schwartz, 1992), opposing to the status quo maintenance for the search of independence of action and thought, stimulation and pleasure (Porto \& Pilati, 2010). In this study, even though there is an opposition between those work related values, both positively influenced the dimension Self-training, also suggesting that even having a motivational content related to individual interests (Security and Self-determination and stimulation), such values significantly contribute to OCBs. At the same time, Satisfaction with salary potentially explains the behaviors related to individual qualification, suggesting that the positive evaluation of received salary greatly contributes to Self-training.

In this sense, it is noted that the values of adjusted coefficient of determination showed that the highlighted work related values have a significant contribution to explain the organizational citizenship behaviors because, according to Hair et al. (2009), the bigger the value of $\mathrm{R}^{2}$ is, whose variation situates between 0 and 1 , the better the preview of the dependent variable is. However, even presenting significant values, the adjusted coefficient of determination showed that there are other independent variables, not analyzed in this study, which also influence the OCBs, reinforcing the necessity of enlarging the research about the subject.

In view of the results, we prepared Table 10 which covers the tested hypotheses and their acceptance or rejection. Please note that all hypotheses were significant at $1 \%$. 
Table 10

Summary of tested hypotheses

\begin{tabular}{|c|c|c|}
\hline Constructs & Hypotheses & Supported \\
\hline \multirow{6}{*}{ Work related values } & H1: Self-determination and stimulation influence the Organizational Citizenship Behaviors. & yes \\
\hline & H2: Security influences the Organizational Citizenship Behaviors. & yes \\
\hline & H3: Conformity influences the Organizational Citizenship Behaviors. & yes \\
\hline & H4: Universalism and benevolence influence the Organizational Citizenship Behaviors. & yes \\
\hline & H5: Realization influences the Organizational Citizenship Behaviors. & yes \\
\hline & H6: Power influences the Organizational Citizenship Behaviors. & no \\
\hline \multirow{5}{*}{ Work Satisfaction } & H7: Satisfaction with workmates influences the Organizational Citizenship Behaviors. & yes \\
\hline & H8: Satisfaction with salary influences the Organizational Citizenship Behaviors. & yes \\
\hline & H9: Satisfaction with boss influences the Organizational Citizenship Behaviors. & yes \\
\hline & H10: Satisfaction with nature of work influences the Organizational Citizenship Behaviors. & no \\
\hline & H11: Satisfaction with promotions influences the Organizational Citizenship Behaviors. & yes \\
\hline
\end{tabular}

As can be seen in Table 6, only the hypotheses $\mathrm{H} 6$ and $\mathrm{H} 10$ were not supported. These results show that the factors power and satisfaction with the nature of work were not significant to influence the OCB in this context. We also have to consider that the power value had the lowest average among the work related values, and the satisfaction with the nature of work factor showed low reliability, and this last one was excluded from the analysis.

Specifically, in the context investigated, such results suggest that for education professionals, the values Conformity and Universalism and benevolence and Security were the main predictors of Organizational Citizenship Behaviors ( $\mathrm{H} 2, \mathrm{H} 3$ and $\mathrm{H} 4)$, signaling that the priority values associated to the social nature of content (universalism and benevolence) and stability (Conformity and Security) have more influence on the OCB. These results refer to the understanding that for the professionals studied, the common good and social harmony stand above individual interests, exerting significant impact on their Organizational Citizenship Behaviors. As pointed out by Gouveia and Clement (2000), with the aim of promoting the collective wellbeing and social harmony, individuals with collectivist values are encouraged to suppress some of their personal desires, presenting as results interdependence, social support and the common destiny. These aspects are closely linked to Organizational Citizenship Behaviors

It was also found that the work related values identified as Self-Determination and Realization had an impact on Organizational Citizenship Behaviors (H1 and H5), confirming the theoretical assumptions suggested by Liang (2012) that the intrinsic values of work as Selfdetermination and Realization may also stimulate collectivism and OCB oriented behavior.

In relation to job satisfaction, there was a higher appreciation of satisfaction with the boss and satisfaction with workmates, and these factors are the main predictors of OCB (H7 and H9) and we might infer the importance of interpersonal relationships, specifically in the context of professional education sector. Beyond these factors, satisfaction with salary and satisfaction with promotions were also considered by respondents as antecedent of OCB (H8 and $\mathrm{H} 11$ ), indicating that these dimensions mainly influence the creative suggestions, favorable organizational climate and self-training.

These findings suggest some considerations about the employees of the education sector investigated. The first regards the reasons why these individuals want to work, which are associated to compliance and collective interests, which are also the main background of OCB practiced by these professionals. The second relates to their 
satisfaction with working, which also suggests the importance of community and relationships in this context. These findings help to strengthen the central role of the education sector as an instrument of social transformation, establishing new perspectives for the future (Monteiro, 2009), to enhance the common and collective interests and satisfaction in an interpersonal level, which influenced the Organizational Citizenship Behavior practiced by these workers.

Yet, the estimated models' assumptions were tested. The Durbin Watson test was performed in order to verify the independence of the regression residuals. The test, according to Pestana and Gageiro (2008), should answer the assumption of null covariance. To test the models' normality, the Kolmogorov-Smirnov test (KS) was performed, under the null hypothesis that the distribution of the tested series is normal (Hair et al., 2009). The premise of factors multicollinearity was verified through Statistical tolerance (TOL) and Variance inflation factors (VIF), which exist only in models with more than one independent variable. Thus, one can confirm that all the models met such requirements.

Finally, the assumption of homoscedasticity was verified, with the application of PesaranPesaran test, which detects the presence of constant variances of residuals based on the results of the regression, in which the dependent variable is Pesaran-Pesaran and the independent variable is the estimated value of the original dependent variable (Hair et al., 2009). Most models met the requirements of homoscedasticity, except for the models Protection of the system and Environment preservation (sig $<0.05)$, which also presented the smaller adjusted determination coefficients ( $\mathrm{R}^{2}$ Adj. 0.061 and 0.062, respectively). The estimated assumptions of regression models can be seen in Table 11 .

Table 11

Assumptions of regression models

\begin{tabular}{|c|c|c|c|c|c|}
\hline Dependent Variable & $\begin{array}{l}\text { Durbin } \\
\text { Watson }\end{array}$ & KS sig & Tol & VIF & Pesaransig \\
\hline Creative Suggestions & 1.90 & 0.35 & 0.59 & 1.68 & 0.12 \\
\hline Friendly Mood & 1.74 & 0.06 & 0.71 & 1.40 & 0.23 \\
\hline Workmate Cooperation & 2.10 & 0.14 & 0.67 & 1.49 & 0.06 \\
\hline Self-training & 1.85 & 0.21 & 0.66 & 1.57 & 0.14 \\
\hline Protection of the system & 1.64 & 0.00 & 0.73 & 1.31 & 0.00 \\
\hline Environment Preservation & 2.09 & 0.21 & 0.84 & 1.19 & 0.00 \\
\hline General Citizenship & 1.78 & 0.23 & 0.68 & 1.46 & 0.06 \\
\hline
\end{tabular}

In general, the results found in regression models lead to a comprehension that work related values and satisfaction at work positively influence the organizational citizenship behaviors. It is valid to highlight that the only independent value that did not influence the OCBs was the value Power. As Schwartz (1992) states, this value is associated to social status and prestige, control or dominance over people and resources (authority, social power), evidencing that its motivational content does not have the potential to influence the organizational citizenship behaviors, commonly associated to dimensions of help, sportsmanship, obedience, and civic virtue.

\section{Final considerations}

Considering that organizational citizenship behaviors have been little explored in the national context, when compared to international studies, and that the antecedents of such behaviors need a bigger comprehension, this study analyzed the influence of work related values and work satisfaction over the OCBs, according to the perspective of employees of a business in the educational sector. 
Initially, the exploratory factor analysis of each one of the scales was performed (Revisited Scale of Work related values, R-SWRV; Satisfaction at Work Scale, SWS; Scale of Civism in Organizations, SCO), and in general it is possible to see adequacy and reliability in the obtained factors. It was verified that the predominant values among the interviewees were Conformity, Realization and Security. Besides, it can be observed more contentment concerning Satisfaction with boss, and Satisfaction with workmates, as well as bigger averages related to the OCBs which refer to Working environment preservation, Protection of the system, and to Creation of a friendly mood to the organization.

Through the multiple regression analysis, it was observed that work related values and work satisfaction influence the OCBs. The model with bigger power of explanation was represented by the dependent variable General citizenship, whose variance was explained in $34 \%$ by the factors Universalism and benevolence, Conformity and by the factor Satisfaction with the boss.

The results obtained in this study suggest some reflections about the antecedents of organizational citizenship behaviors. In relation to satisfaction at work, the relevance of Satisfaction with the boss is highlighted, considered the most influent independent variable over the OCBs, suggesting the relevance of the leader's role in promoting such acts in the working environment, encouraging cooperation between workmates, initiative, and creativity, as well as promoting a friendly working mood.

Another finding is reflected on the values whose focus is related to collective interests (Universalism and benevolence, and Conformity) and values corresponding to individual interests (Realization, Self-determination and stimulation), both in this study influenced the organizational citizenship behaviors. Thus, it can be understood that work related values, regardless of the interests prioritized by individuals, which can be individual or collective, act as antecedents of OCBs.

The same way, values associated to the opposing poles Self-transcendence (Universalism and benevolence) versus (Self-promotion) and Conservation (Conformity and security) versus opening to change (Self-determination and stimulation), also positively influenced the OCBs. These findings contribute to amplify considerations concerning OCBs, whose dimensions also reflect distinct axes. For example, the organizational citizenship behaviors oriented to challenges (Van Dyne et al., 1995), as Altruism, Individual initiative (Podsakoff et al., 2000), and Creative suggestions (Katz \& Kahn, 1978; Porto \& Tamayo, 2003a); and others turned to affiliation (Van Dyne et al., 1995), as the dimensions Sportsmanship, Organizational loyalty, Obedience (Podsakoff et al., 2000), Creation of a friendly mood to the organization in external environment and Protective actions to the system (Katz \& Kahn, 1978; Porto \& Tamayo, 2003a).

Considering the education sector specifically, this study addresses a very relevant issue in the current context, where the role of education assumes a transforming character, both socially, culturally, politically and economically. The findings of this research revealed the importance attached by the professionals of this sector, especially the values related to the common good and collectivity, as well as satisfaction with interpersonal relationships (with boss and workmates) experienced in the work environment, which are significant predictors of Organizational Citizenship Behaviors. The relevance of the results obtained in this study, besides allowing to analyzing the influence of work values and job satisfaction on OCB, gives the possibility to expand the joint reflection of these constructs, allowing a deeper look at the phenomenon investigated.

Still, it is understood that the work in the education sector has such a configuration that all desirable behaviors cannot be exhaustively prescribed in the job description or contracts, especially considering the individuals who work with teaching (Dipaola \& Tschannen-Moran, 2014), who are the majority of this study's 
participants. So that it is believed that the contribution of this study to companies in this sector remains in the possibility of learning more about how OCB can be grown.

For example, their considerations may be the object of job satisfaction management, when companies wish to stimulate employees to express OCB. Managers interested in promoting these behaviors may emphasize, in addition to the work related values, the satisfaction dimensions associated to these acts, in order to promote better results for their own organizations. Therefore, this is related to what is stated by Tamayo (1998), since he considers that the organizational citizenship behavior is partly determined by the evaluative judgment that individuals make about their work or work situation.

However, it must be highlighted as a limitation that the interactions between the work related values themselves were not assessed in this study to find out if they are configured as opposing poles as signalized in studies developed by Porto and Pilati (2010) and Schwartz (1992). Yet, even presenting significant values, the $\mathrm{R}^{2}$ showed that there are other independent variables, not analyzed in this study, which also influence the OCBs. Thus, room is made for future researches which aim at enlarging the model developed in the present study.

Therefore, it is suggested for future studies to broaden investigations concerning the interactions of work related values, considering the focus of interests and their constitutive poles, regarding the $\mathrm{OCBs}$, from their dimensions and orientations. It is also suggested the conduction of studies that assess the impact of work related values over satisfaction at work and over the OCB and the impact of satisfaction at work over the OCB, considering an integrated model that analyzes explanatory relations between multiple variables simultaneously, through the use of Structural Equation Modeling.

Another suggestion is for the conduction of qualitative studies that deepen the investigations concerning the interactions between work related values and/or work satisfaction and organizational citizenship behaviors, providing elements that amplify the comprehension of the investigated phenomena, based on experiences and subjective perspectives of the subjects.

\section{References}

Arthaud-Day, M. L., Rode, J. C., \& Turnley, W. H. (2012). Direct and contextual effects of individual values on organizational citizenship behavior in teams. Journal of Applied Psychology, 94(4), 792-807.

Andrews, M. C., Kacmar, K. M., \& Kacmar, C. (2014). The meditational effect of regulatory focus on the relationships between mindfulness and job satisfaction and turnover intentions. Career Development International, 19(5), 494-507.

Bateman, T. S., \& Organ, D.W. (1983). Job satisfaction and the good soldier: The relationship between affect and employees "citizenship". Academy of Management Journal, 26(4), 587-595.

Blau, P. M. (1964). Exchange and power in social life. New York: Wiley.

Bogler R., \& Somech A. (2004). Influence of teacher empowerment on teachers' organizational commitment, professional commitment and organizational citizenship behavior in schools. Teaching and Teacher Education, 20(3), 277-289.

Bowling, N. A., Wang, Q., \& Li, H. Y. (2012). The moderating effect of core self-evaluations on the relationships between job attitudes and organizational citizenship behavior. Applied Psychology: an International Review, 61(1), 97-113.

Cammarosano, M., Santos, F. C. A., \& Rojas, F. A. (2014). Valores relativos ao trabalho de pesquisadores em uma organização 
brasileira. Revista de Administração de Empresas, 54(4), 445-457.

Campos, B. A. (2008). Estrutura de valores relativos ao trabalho: Um estudo em empresas juniores. In M. L. M. Teixeira (Ed.), Valores humanos e gestão: Novas perspectivas (pp. 389-408). São Paulo: Serviço Nacional de Aprendizagem Comercial.

Chhetri, P. (2014). The role of cognitive and affective trust in the relationship between organizational justice and organizational citizenship behavior: a conceptual framework. Business: Theory and Practicel Verslas: Teorijair Praktika, 15(2), 170-178.

Cruz, V. M. A. C., Silva, F. F., \& Silva, M. C. A. L. (2015). A gestão e a formação flexível do novo trabalhador. Anais do Encontro Internacional de Formação de Professores e Fórum Permanente de Inovação Educacional, Aracaju, SE, Brasil, 9. Retrieved from https:// eventos.set.edu.br/index.php/enfope/article/ view/1432/163

Dipaola, M., \& Tschannen-Moran, M. (2014). Organizational citizenship behavior in schools and its relationship to school climate. Journal of School Leadership, 11(5), 424-447.

Dose, J. (1997). Work values and integrative framework and illustrative application to organizational socialization. Journal of Occupational and Organizational Psychology, 7O(1), 219-241.

Eisenberger, R., Armeli, S., Rexwinkwl, B., Lynch, P., \& Rhoades, L. (2001). Reciprocation of perceived organizational support. Journal of Applied Psychology, 86(51), 42-51.

Elizur, D., \& Sagie, A. (1999). Facets of personal values: A structural analysis of life and work values. Applied Psychology, 48(1), 73-87.
Ellinger, A. D,, \& Wu, Y. J. (2013) A survey relation between job satisfaction and organizational citizenship behavior (OCB). Management Decision, 51(2), 248-262.

Estivalete, V. F. B., Costa, V. F., \& Andrade, T. (2014).Organizational Citizenship Behavior: a Comparative Study between Brazilian and International Scientific Output from 2002 to 2012. Business and Management Review, 4(3), 427-441.

Fassina, N. E., Jones, D. A., \& Uggerslev, K. L. (2008). Relationship Clean-Up Time: Using meta-analysis and path analysis to clarify relationships among job satisfaction, perceived fairness, and citizenship behaviors. Journal of Management, 34(2), 161-188.

Gouveia, V. V., \& Clemente, M. (2000). $O$ individualismo-coletivismo no Brasil e na Espanha: Correlatos sóciodemográficos. Estudos de Psicologia, 5(2), 317-346.

Gursoy, D., Chi, C. G. Q., \& Karadag, E. (2013). Generational differences in work values and attitudes among frontline and service contact employees. International Journal of Hospitality Management, 32(1), 40-48.

Hair, J. F., Babin, B., Money, A. H., \& Somouel, S. (2005). Fundamentos de métodos de pesquisa em administração. São Paulo: Bookman.

Hair, J. F., Black, W. C., Babin, B. J., Anderson, R. E., \& Tatham, R. L. (2009). Análise multivariada de dados (6a ed.). São Paulo: Bookman.

Hitt, M. A., Miller, C. C., \&Colella, A. (2013). Comportamento organizacional (3a ed.). Rio de Janeiro: LTC.

Imran, H., Arif, I., Cheema, S., \& Azeem, M. (2014). Relationship between job satisfaction, job performance, attitude towards work, and 
organizational commitment. Entrepreneurship and Innovation Management Journal, 2(2), 135-144.

Judge, T., \& Bretz, R. D. (1992). Effects of work on job choise decisions. Journal of Applied Psychology, 77(3), 261-271.

Katz, D., \& Kahn, R. L. (1978). Psicologia social das organizações. São Paulo: Atlas.

Lee, H. W., \& Yen, K. W. (2013). A study of the relationship between work values and career orientation of employed in the high technology industry. Quality \& Quantity, 47(2), 803-810.

Lepine, J. A., Erez, A., \& Johnson; D. E. (2002). The nature and dimensionality of organizational citizenship behavior: A critical review and meta-analysis. Journal of Applied Psychology, 87(1), 52-65.

Liang, Y-W. (2012). The relationships among work values, burnout, and organizational citizenship behaviors. International Journal of Contemporary Hospitality Management, 24(2), 251-268.

Locke, E. A. (1976). The nature and causes of job satisfaction. In M. D. Dunnette (Ed.), Handbook of industrial and organizational psychology (pp. 1297-1349). Chicago: Rand McNally.

Mackenzie, S. B., Podsakoff, P. M., \& Podsakoff, N. P. (2011). Challenge-oriented organizational citizenship behaviors and organizational effectiveness: Do challenge-oriented behaviors really have an impact on the organization's bottom line? PersonnelPsychology, 64(3), 559-592.

Marinova, S., Moon, H., \& Van Dyne, A. L. (2010). Are all good soldier behaviors the same? Supporting multidimensionality of organizational citizenship behaviors based on rewards and roles. Human Relations, 63(10), 1463-1485.

Martins, M. C. F., \& Santos, G. E. (2006) Adaptação e validação de construto da escala de satisfação no trabalho. Psico, 11(2), 195-205.

Monteiro, M. I. N. L. (2009). Educação: Novos cenários e perspectivas. Revista Tempos e Espaços em Educação, 2(2), 107-118.

Mourão, L., Monteiro, A. C. F., \& Viana, V. R. (2014). A influência do desenvolvimento profissional e da identificação organizacional na satisfação no trabalho. Psico, 45(2), 198-208.

Nasra, M. A., \& Heilbrunn, S. (2015). Transformational leadership and organizational citizenship behavior in the Arab Educational System in Israel: The impact of trust and job satisfaction. Educational Management Administration \& Leadership, 43(1), 1-17.

Organ, D. W. (1998). Organizational citizenship behavior: The good soldier syndrome. Canada: Lexington Books.

Organ, D. W. (1997). Organizational citizenship behavior: Its construct clean-up time. Human Performance, 10(2), 85-97.

Organ, D. W., Podsakoff, P. M., \& MacKenzie, S. B. (2006). Organizational citizenship behavior: Its nature, antecedents, and consequences. Thousand Oaks: SAGE Publications.

Pestana, M. H., \& Gageiro, J. (2008). Análise der dados para ciências sociais. A complementaridade do SPSS (5a ed.). Lisboa: Edições Sílabo.

PePodsakoff, N. P., Blume, B. D., Whiting, S. W., \& Podsakoff, P. M. (2009). Individualand organizational-level consequences of organizational citizenship behaviors: A metaanalysis. Journal of Applied Psychology, 94(1), 122-141. 
Podsakoff, N. P., Podsakoff, P. M., Mackenzie, S. B., Maynes, T., \& Spoelma, T. (2014). Consequences of unit-level organizational citizenship behaviors: A review and recom mendations for future research. Journal of Organizational Behavior, 35(51), S87-S119.

Podsakoff, P. M., Mackenzie, S. B., Paine, J. B., \& Bachrach, D. G. (2000). Organizational citizenship behaviors: A critical review of the theoretical and empirical literature and suggestions for future research. Journal of Management, 26(3), 513-563.

Porto, J. B., \& Pilati, R. (2010). Escala revisada de valores relativos ao trabalho - EVT-R. Psicologia: Reflexâo e Crítica, 23(1), 73-82.

Porto, J. B., \& Tamayo, A. (2003a). Desenvolvimento e validação da escala de civismo nas organizaçóes. Estudos de Psicologia, 8(1), 393-402.

Porto, J. B., \& Tamayo, A. (2003b). Escala de valores relativos ao trabalho - EVT. Psicologia: Teoria e Pesquisa, 19(2), 145-152.

Porto, J. B., \& Tamayo, A. (2007). Estrutura dos valores pessoais: A relação entre valores gerais e laborais. Psicologia: Teoria e Pesquisa, 23(1), 63-70.

Rapp, A. A., Bachrach, D. G., \& Rapp, T. L. (2013).The influence of time management skill on the curvilinear relationship between organizational citizenship behavior and task performance. Journal of Applied Psychology, 98(4), 668-677.

Robbins, S. P. (2008). Fundamentos do comportamentoorganizacional. Sáo Paulo: Prentice Hall.

Roe, R., \& Ester, P. (1999). Values and work: Empirical findings and theoretical perspectives. Applied Psychology: An International Review, 48(1), 1-21.
Ros, M., Schwartz, S. H., \& Surkiss, S. (1999). Basic individual values, work values, and the meaning of work. Applied Psychology: An Internacional Review, 48(1), 49-71.

Rosa, M. P. A.; Catelli, F., \& Pauletti, F. (2014). "Eu não sei o que o amanhã trará": A tríade tecnologias, sociedade e educação/"I know not what tomorrow will bring": The triad technology, society and education. Acta Scientiae, 16(1), 164-179.

Ryan, J. J. (2002). Work values and organizational citizenship behaviors: Values that work for employees and organizations. Journal of Businessand Psychology, 17(1), 123-132.

Sangwan, A. (2013). Determinants of job satisfaction: A study of insurance sector employees. International Journal of Marketing and Technology, 3(5), 1-19.

Schwartz, S. H. (1992). Universals in the Content and Structure of Values: Theoretical Advances and Empirical Tests in 20 Countries. Advances in Experimental Social Psychology, 25, 1-65.

Shao, P., Resick, C. J., \& Hargis, M. B. (2011). Helping and harming others in the workplace: The roles of personal values and abusive supervision. Human Relations, 64(8), 10511078.

Siqueira, M. M. M. (1995). Antecedentes de comportamentos de cidadania organizacional: a análise de um modelo pós-cognitivo (Tese de doutorado). Universidade de Brasília, Brasília, GO, Brasil.

Siqueira, M. M. M. (2003). Proposição e análise de um modelo para comportamentos de cidadania organizacional. Revista de Administração Contemporânea, 7(SPE), 165-184.

Siqueira, M. M. M. (2008). Satisfação no trabalho. In M. M. M. Siqueira, M. M. M. (Coord.), 
Medidas de comportamento organizacional (pp. 265-274). Porto Alegre: Artmed.

Spector, P. E. (1997). Job satisfaction: Application, assessment, causes, and consequences. Thousand Oaks: Sage Publications.

Spector, P. E. (2012). Psicologia nas organizações (4a ed.). São Paulo: Saraiva.

Swaminathan, S., \& Jawahar, P. D. (2013). Job satisfaction as a predictor of organizational citizenship behavior: An empirical study. Global Journalof Business Research, 7(1), 71-80.

Tamayo, A. (1998). Valores organizacionais: Sua relação com satisfação no trabalho, cidadania organizacional e comprometimento afetivo. Revista de Administração, 33(3), 56-63.

Van Dyne, L., Cummings, L. L., \& Parks, J. M. (1995). Extra-role behaviors: In pursuit of construct and definitional clarity. In L. L. Cummings \& B. M. Staw (Eds.), Research in organizational behavior (Vol. 17, pp. 215285). London: JAI Press.

Van Dyne, L., Ang, S., \& Koh, C. (2008). Development and validation of the CQS: The cultural intelligence scale. In S. Ang \& L. Van Dyne (Eds.), Handbook on cultural intelligence: Theory, measurement and applications (pp. 16-38). New York: M. E. Sharpe.
Vieira, K. M., \& Dalmoro, M. (2008). Dilemas na Construção de Escalas Tipo Likert: o Número de Itens e a Disposição Influenciam nos Resultados? Anais do ENANPAD - Encontro Nacional dos Cursos de Pós Graduação em Administração, Rio de Janeiro, RJ, Brasil, 32.

Wang, H., Law, K. S., Hackett, R. D., Wang, D., \& Chen, Z. X. (2005). Leader-Member exchange as a mediator of the relationship between transformational leadership and followers' performance and organizational citizenship behavior. The Academy of Management Journal, 48(3), 420-432.

Williams, L. J., \& Anderson, S. E. (1991). Job satisfaction and organizational commitment as predictors of organizational citizenship and in-role behaviors. Journal of Management, 17(3), 601-617.

Yaghoubi, N. M., Yazdani, B. O., \& Khornegah, K. (2011). The Relationship between Organizational Citizenship Behavior (OCB) and Social Capital (SC). American Journal of Scientific Research, 24, 121-126.

Zeinabadi, H. (2010). Job satisfaction and organizational commitment as antecedents of Organizational Citizenship Behavior (OCB) of teachers. Procedia Social and Behavioral Sciences, 5, 998-1003 


\section{About the authors:}

1. Taís de Andrade, MSc in Management, Federal University of Santa Maria, Brazil.

E-mail: tais0206@gmail.com.

2. Vivian Flores Costa, MSc in Management, Federal University of Santa Maria, Brazil.

Email: vivianfc13@gmail.com

3. Vania de Fátima Barros Estivalete, PhD in Economic Sociology of Organizations, University of Lisbon. E-mail: vaniaestivalete@ufsm.br

4. Leticia Lengler, MSc in Management, Federal University of Rio Grande do Sul, Brazil.

E-mail: llenglerworld@yahoo.com

\section{Contribution of each author:}

\begin{tabular}{|c|c|c|c|c|}
\hline Contribution & $\begin{array}{l}\text { Taís de } \\
\text { Andrade }\end{array}$ & $\begin{array}{l}\text { Vivian } \\
\text { Flores Costa }\end{array}$ & $\begin{array}{c}\text { Vania de } \\
\text { Fátima Barros } \\
\text { Estivalete }\end{array}$ & $\begin{array}{l}\text { Leticia } \\
\text { Lengler }\end{array}$ \\
\hline 1. Definition of research problem & $\sqrt{ }$ & & $\sqrt{ }$ & \\
\hline $\begin{array}{l}\text { 2. Development of hypotheses or research questions } \\
\text { (empirical studies) }\end{array}$ & $\sqrt{ }$ & $\sqrt{ }$ & $\sqrt{ }$ & $\sqrt{ }$ \\
\hline $\begin{array}{l}\text { 3. Development of theoretical propositions } \\
\text { (theoretical Work) }\end{array}$ & $\sqrt{ }$ & & & \\
\hline 4. Theoretical foundation/ Literature review & $\sqrt{ }$ & $\sqrt{ }$ & & \\
\hline 5. Definition of methodological procedures & & & $\sqrt{ }$ & \\
\hline 6. Data collection & $\sqrt{ }$ & & & \\
\hline 7. Statistical analysis & $\sqrt{ }$ & $\sqrt{ }$ & $\sqrt{ }$ & \\
\hline 8. Analysis and interpretation of data & $\sqrt{ }$ & & & $\sqrt{ }$ \\
\hline 9. Critical revision of the manuscript & $\sqrt{ }$ & $\sqrt{ }$ & $\sqrt{ }$ & $\sqrt{ }$ \\
\hline 10. Manuscript Writing & $\sqrt{ }$ & $\sqrt{ }$ & & $\sqrt{ }$ \\
\hline
\end{tabular}

